\title{
The problem of evil and images of (in)humanity
}

\author{
Preface by Guest Editors
}

I his special issue of Scandinavian Jewish Studies contains revised versions of six lectures given at a cross-disciplinary workshop and $\mathrm{PhD}$ course entitled 'The Problem of Evil and Images of (In)Humanity', which was organized by Claudia Welz and took place at CJMC: Center for the Study of Jewish Thought in Modern Culture, University of Copenhagen, on 6-7 October 2016 (see the whole programme here).

The contributions address the problem of evil and the ensuing challenge of re-orientation after violent conflicts, wars, and genocide. The potential of imagination is explored as a means of ethical re-orientation and societal integration in the aftermath of atrocity. Given that people can treat their fellow human beings with disrespect and even as if they were sub-human, the question is: What mental, linguistic or graphic images of humanity can yield navigational tools and norms of orientation?

Owing to their overt or covert normativity, images move those who perceive or conceive them. How do images that depict our common humanity differ from counter-images that distort the image of 'the other'? And, more generally, how can destructive images be differentiated from healing images in terms of how they interact with their beholders? Of special interest are differences regarding the pragmatics, functioning, and effects of the images: What are the ways in which they appear to and affect their viewers? The role of re-orienting images is of interest in three respects:

I) regarding their potential to confront perpetrators with their guilt by inviting them to repair their relations to the injured parties, if this is possible, or to take responsibility for the irreparable damage they have caused

2) regarding their potential to help victims to regain their dignity and to deal with overwhelming feelings of grief, powerlessness, anxiety, depression, and shame

3) regarding their potential to prompt critical reflection, empathy, and civil courage in those who witnessed the event, are implicated in it, or at least informed about what happened.

Just as the Copenhagen conference concentrated on different types of images, so this special issue of Scandinavian Jewish Studies investigates visual images (e.g. painted portraits, caricatures, sculptures, photographs, movies, plays, or other performances), their interaction with mental images (e.g. images of memory, dreams, or intuitive notions that are communicated with or without words), and verbal images, that is to say metaphors in written or spoken language. 
Images have the power to make evident what they show. Awareness of this power is also relevant for understanding how enemy propaganda works, where the visual in the service of the verbal can fool people into believing in lies about others.

In particular, the relation between ethics and aesthetics comes into view. It manifests itself in images of (in)humanity that surface in creative responses to dilemmas, double binds and trapping roles. Religious (re)sources are brought together with philosophical and theological traditions in order to map out the manners in which such images can contribute to processes of coping with trauma, of making up for injustice, and of re-establishing a sense of solidarity after crimes against humanity. In this connection the discussion of Jewish thought after the Shoah is of special relevance.

As to the individual contributions, the first article by Eva Schürmann focuses on the interconnectedness of mental and visual images, especially in memories and expectations representing something absent. She explains the ways in which perception is formed by ideas and practices. While her article is a philosophical exploration, the next article by Søren Holst contributes to biblical exegesis in exploring how the psalmists manage to overcome evil with the help of lament and a theology of creation. More precisely, the metaphorical use of the Hebrew word mot, 'to stagger', is surveyed in an attempt to show the transition from despair to trust in God the creator.

The following articles are dedicated to the relation between the problem of evil and images of (in)humanity during and after the Holocaust. Jennifer Geddes demonstrates how verbal images in the testimonies of Primo Levi and Charlotte Delbo served both to maintain a sense of the camp inmates' humanity and depict the Nazis' effort to destroy it. Anna Westin outlines the existential phenomenology of Emmanuel Lévinas in conversation with Søren
Kierkegaard's approach to ethical action on the one hand and with the Jewish concept of tikkun olam, the repair of the world, on the other. Grace Whistler portrays Albert Camus's effort to reestablish morality in the face of suffering not only as a response to Christianity, but also as a 'poetics of secular faith': an innovative attempt at reconciling spirituality and suffering through philosophical literature. Claudia Welz resumes the discussion on the basis of Hannah Arendt's notion of 'rootless evil' and investigates the orienting potential of visual, verbal, and mental images of (in)humanity in regard to images of violence on the one hand, and exemplary counter-images on the other: the biblical imago Dei motif, Michelangelo's Creation of Adam, and Jorge Semprun's testimony about the ambiguity of human freedom.

\section{CATHRINE BJØRNHOLT MICHAELSEN} and CLAUDIA WELZ

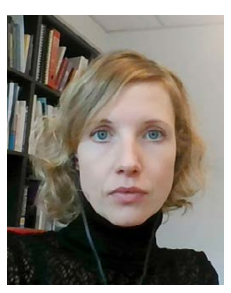

Cathrine Bjørnholt Michaelsen is a post-doctoral researcher at the Department of Management, Politics and Philosophy, Copenhagen Business School. She received her $\mathrm{PhD}$ on 'The Remains of a Self: Solitudes and Responsibilities' from Copenhagen University in 2017 and is also the author of 'Tracing a traumatic temporality: on trauma and responsibility in Derrida and Lévinas', in Levinas Studies (Duquesne University Press, 2016) and 'Ways of dying: the double death in Kierkegaard and Blanchot', in Kierkegaard Studies Yearbook (Walter de Gruyter, 2014).

Claudia Welz is Professor of Systematic Theology with special responsibilities in Ethics and Philosophy of Religion at the University of Copenhagen and Founding Director of CJMC: Center for the Study of Jewish Thought in Modern Culture. She is the author of the monographs Love's

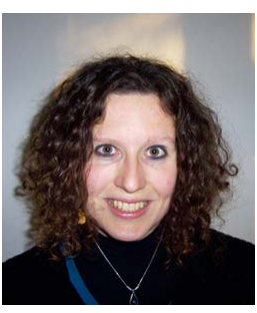

Transcendence and the Problem of Theodicy (Mohr Siebeck, 2008), Vertrauen und Versuchung (Mohr Siebeck, 2010), and Humanity in God's Image: An Interdisciplinary Exploration (Oxford University Press, 2016). 